\title{
Penerapan Supervisi Klinis untuk Meningkatkan Keterampilan Dasar Mengajar Guru di SDN 165/X Catur Rahayu pada Semester Ganjil Tahun Ajaran 2021/2022
}

\author{
Siti Muslimah \\ SDN 165/X Catur Rahayu \\ Jl. Catur Rahayu, Dendang, Kabupaten Tanjung Jabung Timur, Jambi. \\ siti_muslimah@gmail.com
}

\begin{abstract}
This research is motivated by the basic skills of teaching teachers in elementary schools that need to be improved again. The purpose of this study was to obtain information and discuss the application of clinical supervision to improve the basic teaching skills of teachers at SDN.165/X Catur Rahayu in the odd semester of the 2021/2022 academic year. This research is a school action research (PTS) which consists of two cycles where each cycle consists of four stages, namely planning, implementation, observation, and reflection, data collection techniques using observation sheets, field notes, and documentation. Data were analyzed using percentages and data reduction. The results showed that the application of clinical supervision could improve the basic teaching skills of teachers at SDN.165/X Catur Rahayu. Using a clinical supervision approach is an approach in supervision that is considered effective for improving teacher skills in the learning process.
\end{abstract}

Keywords: basic teaching skills, clinical supervision

\begin{abstract}
Abstrak
Penelitian ini dilatarbelakangi keterampilan dasar mengajar guru di sekolah dasar yang perlu untuk ditingkatkan lagi. Tujuan penelitian ini adalah untuk mendapatkan informasi dan membahas tentang penerapan supervisi klinis untuk meningkatkan keterampilan dasar mengajar guru di SDN.165/X Catur Rahayu pada semester ganjil tahun ajaran 2021/2022. Penelitian ini merupakan penelitian tindakan sekolah (PTS) yang terdiri dari dua siklus diaman masing-masing siklur terdiri dari empat tahapan yaitu perencanaan, pelaksanaan, observasi, dan refleksi, Teknik pengumpulan data menggunakan lembar observasi, catatn lapangan, dan dokumentasi. Data dianalisis menggunakan persentase dan reduksi data. Hasil penelitian menunjukkan bahwa melalui penerapan supervisi klinis dapat meningkatkan keterampilan dasar mengajar guru di SDN.165/X Catur Rahayu. Dengan menggunakan pendekatan supervisi klinis adalah suatu pendekatan dalam supervisi yang dianggap efektif untuk meningkatkan keterampilan guru dalam proses pembelajaran.
\end{abstract}

Kata kunci: keterampilan dasar mengajar, supervisi klinis

Copyright (c) 2022 Siti Muslimah

Corresponding author: Siti Muslimah

Email Address: siti_muslimah@gmail.com (Jl.Catur Rahayu, Kabupaten Tanjung Jabung Timur, Jambi)

Received 10 January 2022, Accepted 20 January 2022, Published 18 February 2022

\section{PENDAHULUAN}

Dalam upaya peningkatan mutu pendidikan, sebenarnya tidak hanya dibenankan kepada siswa saja untuk selalu belajar lebih giat dan tekun terutama di saat ini yang merupakan jaman globalisasi di mana perkembangannya sangat cepat yang dibarengi dengan perkembangan ilmu pengetahuan dan teknologi yang setiap saat selalu mengalami perubahan. Pendidikan sendiri merupakan proses pelatihan dan pengembangan pengetahuan, keterampilan, pikiran, karakter, dan seterusnya, khususnya lewat persekolahan formal (Sagala, 2013:1).

Guru sebagai pendidik merupakan faktor yang sangat penting dalam melakukan proses pembelajaran di kelas yang menjadi tanggung jawabnya, juga merupakan faktor penentu dalam upaya 
Penerapan Supervisi Klinis untuk Meningkatkan Keterampilan Dasar Mengajar Guru di SDN 165/X Catur Rahayu pada Semester Ganjil Tahun Ajaran 2021/2022, Siti Muslimah

peningkatan mutu pendidikan di sekolah terutama pada pendidikan dasar dan menengah. Karena pendidikan adalah pemberian pembekalan yang tidak ada pada masa kanak-kanak, akan tetapi kita membutuhkannya pada waktu dewasa.

Guru bertanggung jawab untuk mengantarkan peserta didik ke arah kedewasaan susila yang cakap dengan memberikan sejumlah ilmu pengetahuan dan membimbingnya. Sementara peserta didik berusaha untuk mencapai tujuan tersebut dengan bantuan dan pembinaan dari guru yang profesional. Kemampuan profesionalisme merupakan refleksi dari penerapan kompetensi guru secara holistik. Kompetensi tersebut mencakupi baik kompetensi pedagodik, kompetensi kepribadian, kompetensi sosial, dan kompetensi profesional (UU 20 tahun 2003, UU 14 tahun 2005, PP 19 tahun 2005, PP 74 tahun 2009, dan Permendikans 16 Tahun 2007).

Menurut Mulyasa (2005:20) sedikitnya ada tujuh kesalahan yang sering dilakukan guru dalam pembelajaran yakni: (a) mengambil jalan pintas dalam pembelajaran, (b) menunggu peserta didik berperilaku negatif, (c) menggunakan destruktif disiplin, (d) mengabaikan kebutuhan-kebutuhan khusus (perbedaan individu) peserta didik, (e) merasa diri paling pandai, (f) tidak adil (diskriminatif), dan (g) memaksa hak peserta didik.

Serangkaian potret pembelajaran yang dilakukan guru SDN.165/X Catur Rahayu dapat dimaknai bahwa persoalan mendasar yang perlu mendapatkan perhatian adalah peningkatan keterampilan dasar mengajar agar guru-guru dapat mendesain aktivitas pembelajaran secara bermakna yang menempatkan peserta didik sebagai pengonsumsi gagasan.

Kondisi problematik keterampilan dasar mengajar guru-guru di SDN.165/X Catur Rahayu cukup beragam. Secara umum, guru-guru sudah memiliki keterampilan dasar mengajar. Namun pada tataran pengembangan keterampilan belum menunjukkan perkembangan yang berarti. Guru sudah mendesain proses pembelajaran dengan multimedia dan multimetode, namun intensitas pemanfataannya belum rutin. Rencana Pelaksanaan Pembelajaran (RPP) juga sudah disusun oleh guru dengan menganalisis RPP tahun sebelumnya melalui diskusi dengan teman sejawat dan dalam kegiatan Kelompok Kerja Guru (KKG).

Untuk mengatasi permasalah di atas tersebut maka peneliti sebagai kepala sekolah melaksanakan supervisi klinis sebagai salah satu upaya untuk meningkatkan keterampian dasar mengajar guru. Ada dua asumsi yang mendasari pentingnya supervisi klinis. Pertama, pembelajaran merupakan aktivitas yang sangat kompleks yang memerlukan pengamatan dan analisis secara hatihati. Melalui pengamatan dan analisis ini, seorang supervisor pendidikan akan dengan mudah mengembangkan kemampuan guru dalam mengelola proses pembelajaran. Kedua, guru-guru yang profesionalismenya ingin dikembangkan lebih menghendaki cara kesejawatan daripada cara yang otoriter (Sergiovanni dalam Bafadal, 2004:66).

Berdasarkan uraian di atas, penelitian tindakan sekolah bertujuan untuk meningkatkan keterampilan dasar mengajar melalui supervisi klinis sehingga guru memiliki seperangkat kemampuan untuk mendesain proses pembelajaran yang aktif, kreatif, efektif, menyenangkan, dan inovatif dengan 
melaksanakan penelitian yang berjudul bertujuan untuk mendapatak informasi dan membahas tentang penerapan supervisi klinis untuk meningkatkan keterampilan dasar mengajar guru di SDN.165/X Catur Rahayu pada semester ganjil tahun ajaran 2021/2022.

\section{METODE}

Penelitian ini merupakan penelitian tindakan sekolah (PTS) yang terdiri dari dua siklus diaman masing-masing siklur terdiri dari empat tahapan yaitu perencanaan, pelaksanaan, observasi, dan refleksi, Teknik pengumpulan data menggunakan lembar observasi, catatan lapangan, dan dokumentasi. Data dianalisis menggunakan persentase dan reduksi data.

\section{HASIL DAN DISKUSI}

\section{Siklus I}

\section{Perencanaan}

Dalam perencanaan ini, persiapan yang dilakukan sebelum pelaksanaan tindakan adalah sebagai berikut: 1) Mengumpulkan guru melalui undangan kepala sekolah, 2) Menyusun instrumen, 3) Menyusun jadwal supervisi klinis mulai dari hari, tanggal, jam serta tempat pertemuan, 4) Menyiapkan materi supervisi klinis, 5) Menyuruh guru membawa bahan-bahan yang dibutuhkan saat melakukan supervisi klinis, 6) Menyiapkan konsumsi untuk pertemuan, 7) Menyuruh guru membawa laptop dan media lain yang dibutuhkan.

\section{Pelaksanaan}

Pada siklus I ini pelaksanaan dilakukan oleh peneliti sebanyak 3 kali pertemuan dimana masing-masing pertemuan peneliti memberikan pemhaman konsep berupa materi-materi kepada guruguru tersebut dan pertemaun kedua meminta guru-guru tersebut untuk mengaplikasikannya di dalam pembelajaran. Siklus I dilaksanakan pada hari Senin tanggal 13 September 2021 dengan memberikan materi kepada guru dan kemudian pada hari Senin tanggal 20 September dan Rabu 22 sepetember 2021 guru diminta mengaplikasikannya dan peneliti mensupervsi dari masing-masing kegiatan guru tersebut.

Pelaksanaan siklus 1 terdiri atas: (1) membangun hubungan antara guru dengan kepala sekolah, (2) guru diminta berkonsultasi mengenai kesulitan-kesulitan yang dihadapi dalam pembelajaran kesulitan yang dihadapi, (3) kepala sekolah memberikan arahan dan solusi terhadap permasalahan yang diajukan guru tanpa memberikan umpan balik, (4) kepala sekolah meneliti Rencana Pelaksanaan Pembelajaran (RPP) guru yang akan digunakan dalam proses pembelajaran, (5) kepala sekolah mengamati proses pembelajaran guru secara langsung di dalam kelas dengan memfokuskan pada penguasaan 8 (delapan) keterampilan dasar mengajar, (6) kepala sekolah menganalisis proses pembelajaran dari awal sampai akhir dan memberikan catatan analisisnya kepada guru. 
Penerapan Supervisi Klinis untuk Meningkatkan Keterampilan Dasar Mengajar Guru di SDN 165/X Catur Rahayu pada Semester Ganjil Tahun Ajaran 2021/2022, Siti Muslimah

Pada siklus I ini materi yang disampaikan oleh kepala sekolah berupa keterampilan dasar mengajar yang harus dimiliki oleh seorang guru yang dalam penelitian ini dibatasa pada 8 keterampilan yaitu 1) keterampilan membuka dan menutup pembelajaran , (2) keterampilan menjelaskan, (3) keterampilan mengadakan variasi, (4) keterampilan memberikan penguatan , (5) keterampilan bertanya, (6) keterampilan mengelola kelas, (7) keterampilan mengajar kelompok kecil dan perorangan, dan (8) keterampilan membimbing diskusi kelompok kecil.

Dari 8 keterampilan tersbut dijelaskan oleh peneliti kepada guru saat pertemuan pertama dan terjadi tanya jawab antara peneliti dan guru mengenai 8 keterampilan tersebut. Setelah mendapat materi tersebut pada pertemuan selanjutnya maka guru-guru tersebut mengaplikasikannya ke dalam kelas dan kepala sekolah mensupervisi masing-masing guru yang menjadi subjek dalam penelitian ini. Dari 5 orang guru yang menjadi subjek dalam penelitian ini merupakan guru kelas dan guru mata pelajaran.

\section{Observasi}

Kegiatan observasi pada siklus 1 dilaksanakan secara kolaboratif dengan melibatkan kepala sekolah dan observer untuk mengamati proses pembelajaran yang dilakukan guru. Observasi dilakukan dengan lembar observasi yang memfokuskan pada keterampilan dasar mengajar guru. Pada tahap observasi ini akan menjelaskan hasil dari observasi yang dilakukan oleh peneliti yang dibantu oseorang observer selama kegiatan pelaksanaan berlangsung. Hasil observasi siklus I dapat dilihat pada tabel berikut ini:

Tabel 1. Hasil Observasi Keterampilan Dasar Mengajar Guru pada Siklus I

\begin{tabular}{|c|l|c|c|c|c|}
\hline No & \multicolumn{1}{|c|}{ Nama } & Jumlah & $\begin{array}{c}\text { Rata- } \\
\text { Rata }\end{array}$ & $\%$ & Keterangan \\
\hline 1 & SUGIARTI,S.Pd.SD & 24 & 3 & 75 & Cukup \\
\hline 2 & SRI MULYANI, S.Pd. SD & 20 & 2.5 & 63 & Kurang \\
\hline 3 & JONI RABUAN,S.Pd & 20 & 2.5 & 63 & Cukup \\
\hline 4 & YUHANES,A.Ma & 26 & 3.25 & 81 & Baik \\
\hline 5 & ADE MARDIAN SYAHPUTRA ,S.Or & 21 & 2.625 & 66 & Kurang \\
\hline \multicolumn{4}{|c|}{ Rerata } & 69 & Kurang \\
\hline
\end{tabular}

Berdasarkan tabel di atas dapat dilihat bahwa dari 5 orang guru yang menjadi subjek dalam penelitian ini secara keseluruahn masih berada dalam kategori kurang yaitu sebesar $69 \%$, hanya terdapat 1 orang guru yang dinilai keterampilan dasar mengajarnya sudah berada dalam kategori baik. Untuk itu perlu halnya perbaikan-perbaikan yang dilakukan oleh kepala sekolah pada siklus berikutnya. Untuk melihat penguasaan guru terhadap masing-masing indikator penilaian dalam keterampilan dasar mengajar dapat dilihat pada tabel beriku ini: 
Tabel 2. Penilaian Masing-masing Indikator Keterampilan dasar Mengajar Siklus I

\begin{tabular}{|c|c|c|c|c|c|}
\hline No & Indikator Penilaian & Jumlah & $\begin{array}{l}\text { Rata- } \\
\text { Rata }\end{array}$ & $\%$ & Keterangan \\
\hline 1 & $\begin{array}{l}\text { Keterampilan membuka dan menutup } \\
\text { pembelajaran }\end{array}$ & 13 & 2.6 & 65 & Kurang \\
\hline 2 & Keterampilan menjelaskan & 12 & 2.4 & 60 & Kurang \\
\hline 3 & Keterampilan mengadakan variasi & 17 & 3.4 & 85 & Baik \\
\hline 4 & Keterampilan memberikan penguatan & 12 & 2.4 & 60 & Kurang \\
\hline 5 & Keterampilan bertanya & 15 & 3 & 75 & Cukup \\
\hline 6 & Keterampilan mengelola kelas & 13 & 2.6 & 65 & Kurang \\
\hline 7 & $\begin{array}{l}\text { Keterampilan mengajar kelompok kecil } \\
\text { dan perorangan }\end{array}$ & 12 & 2.4 & 60 & Kurang \\
\hline 8 & $\begin{array}{l}\text { Keterampilan membimbing diskusi } \\
\text { kelompok kecil }\end{array}$ & 17 & 3.4 & 85 & Baik \\
\hline \multicolumn{4}{|c|}{ Rerata } & 69 & Kurang \\
\hline
\end{tabular}

Berdasarkan tabel di atas dapat disimpulkan bahwa penguasaan masing-masing guru terhadap 8 indikator penilaian keterampilan dasar mengajar masih rendah. 2 indikator yang sudah berada pad kategori baik yaitu keterampilan mengadakan variasi dan keterampilan membimbing diskusi kelompok kecil yang dinilai guru sudah mampu melaksanakannnya. Sedangakan 6 indikator lainya masih berada pada kategori cukup dan kurang. Untuk lebih jelas dapat dilihat pada gambar berikut ini:

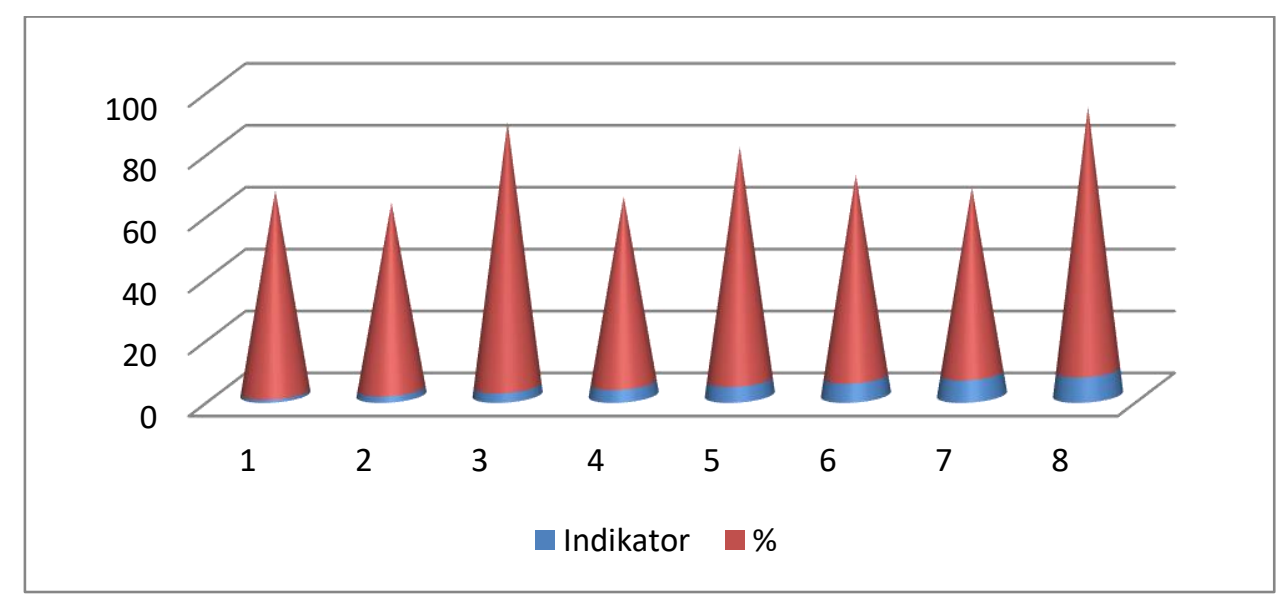

Gambar 1. Penilaian Masing-masing Indikator Keterampilan dasar Mengajar Siklus I

Dari gambar di atas dapat disimpulkan bahwa pada siklus I keterampilan dasar mengaar guru masih rendah dan perlu adanya perbaikan-perbaikan pada siklus berikutnya. Untuk itu pada siklus II peneliti akan mangadakan perubahan tindakan dalam melaksanakan supervisi untuk meningkatkan keterampilan dasar mengajar guru.

\section{Refleksi}

Tahap refleksi siklus I dilaksanakan pada hari Rabu tanggal 29 September 2021 yang dibantu oleh seorang observer yang bernama Siti Zahara, S.Pd. bertempat di ruangan kepala SDN 165/X Catur Rahayu. Pada tahap ini peneliti dan observer membahas kendala-kendala yang terdapat selama pelaksanaan siklus I dan hasil observasi serta mencari solusi atau pemecahan dari masalah tersebut 
Penerapan Supervisi Klinis untuk Meningkatkan Keterampilan Dasar Mengajar Guru di SDN 165/X Catur Rahayu pada Semester Ganjil Tahun Ajaran 2021/2022, Siti Muslimah

agar pada siklus II tidak terjadi lagi. Kegiatan refleksi siklus 1 berupa mengkaji dan mengevaluasi penguasaan keterampilan dasar mengajar guru dan menyesuaikan dengan ketercapaian indikator kinerja sehingga peneliti mengubah strategi pada siklus berikutnya agar pelaksanaannya lebih efektif.

Pada siklus I didapat adanya guru yang masih terkendala dalam melengkapi administrasi pemebelajaran terlebih dahulu sebelum menerapkan pembelajaran di kelas. Selain itu juga ada guru yang terkendala cara mengelola kelas dan memebrikan penguatan yang baik kepada peseta didik. Untuk itu pada siklus II peneliti sebelum melaksanakan supervisi terlebh dahulu akan mengecek kelengkapan adminitrasi pembelajaran guru dan akan memberikan penguatan materi mengenai pengelolaan pembelajaran yang baik dan menarik minat peserta didik sehingga mereka bersemangat dan hasil nya pun juga meningkat.

\section{Siklus II}

\section{Perencanaan}

Dalam perencanaan ini siklus II, persiapan yang dilakukan sebelum pelaksanaan tindakan sama halnya dengan perencanaan pada siklus I adalah sebagai berikut: 1) Mengumpulkan guru melalui undangan kepala sekolah, 2) Menyusun instrumen, 3) Menyusun jadwal supervisi klinis mulai dari hari, tanggal, jam serta tempat pertemuan, 4) Menyiapkan materi supervisi klinis, 4) Menyuruh guru membawa bahan-bahan yang dibutuhkan saat melakukan supervisi klinis, 5) Menyiapkan konsumsi untuk pertemuan, 6) Menyuruh guru membawa laptop dan media lain yang dibutuhkan, 7) Meminta guru untuk mengumpulkan adminitrasi pembelajaran..

\section{Pelaksanaan}

Pelaksanaan pada siklus II dilaksanakan selama 3 tg pertemuan sama halnya juga dengan pertemuan siklus I yang dilaksanakan pada hari Senin tanggal 4 Oktober 2021 dengan agenda memberikan penguatan materi kembali mengenai keterampilan dasar mengajar, kemudian hari Senin tanggal 11 Oktober 2021 dan hari Rabu tanggal 13 Oktober 2021 yaitu dengan agenda pengaplikasian materi yang telah disampaikan.

Fokus pelaksanaan pada siklus 2 mencakupi aktivitas: (1) membangun hubungan antara guru dengan kepala sekolah, (2) guru diminta menuliskan kesulitankesulitan yang dihadapi dalam pembelajaran khususnya yang terkait dengan keterampilan dasar mengajar, (3) kepala sekolah memberikan masukan alternatif untuk mengatasi permasalahan yang dihadapi guru secara interaktif, (4) kepala sekolah meneliti RPP guru yang akan digunakan dalam proses pembelajaran dan membenarkan apabila terdapat kekeliruan/kekurangan dalam menyusun RPP, (5) kepala sekolah mengamati proses pembelajaran guru secara langsung di dalam kelas dengan memfokuskan pada penguasaan 8 (delapan) keterampilan dasar mengajar, (6) kepala sekolah menganalisis proses pembelajaran dengan member kesempatan kepada guru untuk menyampaikan permasalahanpermasalahan yang dihadapi dalam pembelajaran yang telah dilakukan, dan (7) kepala sekolah memberikan masukan kepada guru terhadap temuan-temuan sebagai upaya umpan balik proses pembelajaran. 


\section{Observasi}

Kegiatan observasi pada siklus II dilaksanakan secara kolaboratif dengan melibatkan kepala sekolah dan observer untuk mengamati proses pembelajaran yang dilakukan guru. Observasi dilakukan dengan lembar observasi yang memfokuskan pada keterampilan dasar mengajar guru. Pada tahap observasi ini akan menjelaskan hasil dari observasi yang dilakukan oleh peneliti yang dibantu oseorang observer selama kegiatan pelaksanaan berlangsung. Hasil observasi siklus II dapat dilihat pada tabel berikut ini:

Tabel 3. Hasil Observasi Keterampilan Dasar Mengajar Guru pada Siklus II

\begin{tabular}{|c|l|c|c|c|c|}
\hline No & Nama & Jumlah & $\begin{array}{c}\text { Rata- } \\
\text { Rata }\end{array}$ & $\%$ & Keterangan \\
\hline 1 & SUGIARTI,S.Pd.SD & 30 & 3.75 & 94 & Amat Baik \\
\hline 2 & SRI MULYANI,S.Pd.S & 27 & 3.375 & 84 & Baik \\
\hline 3 & JONI RABUAN,S.Pd & 29 & 3.625 & 94 & Amat Baik \\
\hline 4 & YUHANES,A.Ma & 30 & 3.75 & 94 & Amat Baik \\
\hline 5 & $\begin{array}{l}\text { ADE MARDIAN } \\
\text { SYAHPUTRA ,S.Or }\end{array}$ & 28 & 3.5 & 88 & Baik \\
\hline
\end{tabular}

Berdasarkan tabel di atas dapat disimpulkan bahwa hasi observasi keterampilan dasar mengajar dari 5 orang guru yang menjadi subjek dalam penelitian ini sudah meningkat dari siklus seblumnya. Hal ini dapat dilihat rata-rata perolehan dari seluruh subjek penelitian berada pada kategori amat baik dengan $91 \%$. Hal ini berarti pada siklus II terjadinya perbaikan-perbaiakn tindakan yang sangat dapat membantu guru. Untuk melihat penguasaan guru terhadap masing-masing indikator penilaian dalam keterampilan dasar mengajar dapat dilihat pada tabel beriku ini:

Tabel 4. Penilaian Masing-masing Indikator Keterampilan dasar Mengajar Siklus II

\begin{tabular}{|c|c|c|c|c|c|}
\hline No & Indikator Penilaian & Jumlah & $\begin{array}{l}\text { Rata- } \\
\text { Rata }\end{array}$ & $\%$ & Keterangan \\
\hline 1 & $\begin{array}{l}\text { Keterampilan membuka dan menutup } \\
\text { pembelajaran }\end{array}$ & 18 & 3.6 & 90 & Amat Baik \\
\hline 2 & Keterampilan menjelaskan & 17 & 3.4 & 85 & Baik \\
\hline 3 & Keterampilan mengadakan variasi & 19 & 3.8 & 95 & Amat Baik \\
\hline 4 & Keterampilan memberikan penguatan & 16 & 3.2 & 80 & Baik \\
\hline 5 & Keterampilan bertanya & 19 & 3.8 & 95 & Amat Baik \\
\hline 6 & Keterampilan mengelola kelas & 19 & 3.8 & 95 & Amat Baik \\
\hline 7 & $\begin{array}{l}\text { Keterampilan mengajar kelompok kecil } \\
\text { dan perorangan }\end{array}$ & 18 & 3.6 & 90 & Amat Baik \\
\hline 8 & $\begin{array}{l}\text { Keterampilan membimbing diskusi } \\
\text { kelompok kecil }\end{array}$ & 19 & 3.8 & 95 & Amat Baik \\
\hline \multicolumn{4}{|c|}{ Rerata } & 91 & Amat Baik \\
\hline
\end{tabular}

Dari tabel di atas dapat dilihat bahwa penguasaan guru terhadapa masing-masing indikator penilaian dalamn keterampilan dasar mengajar sudah meningkat dengan berada pada kategori amat baik dengan persentase sebesar 91\%. Dari 8 indikator keterampilan dasar mengajar guru di dapat 
Penerapan Supervisi Klinis untuk Meningkatkan Keterampilan Dasar Mengajar Guru di SDN 165/X Catur Rahayu pada Semester Ganjil Tahun Ajaran 2021/2022, Siti Muslimah

bahwa 2 indikator berada pada ketegori baik yaitu keterampilan menjelaskan dan keterampilan memberikan penguatan, sedangkan 6 indikator lainnya sudah berada pada kategori amat baik. Untuk lebih jelas dapat dilihat pada gambar berikut.

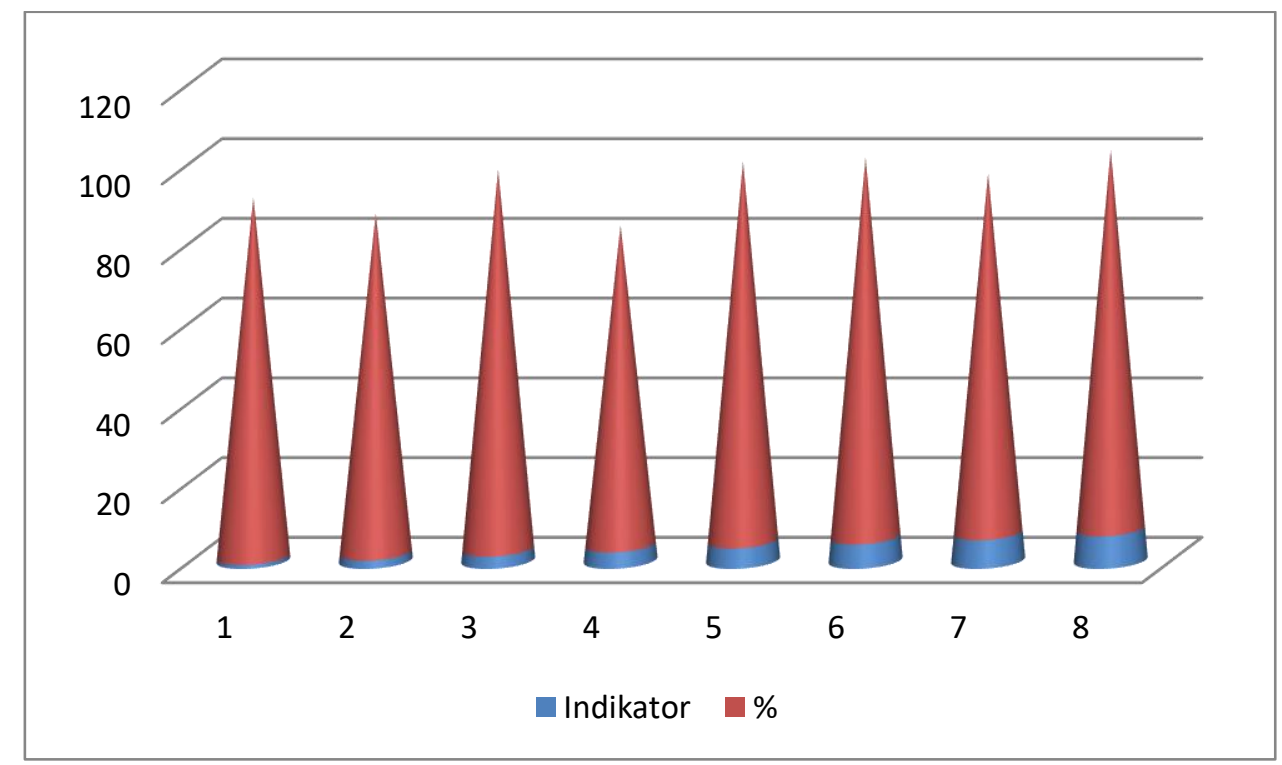

Gambar 4.2 Penilaian Masing-masing Indikator Keterampilan dasar Mengajar Siklus II

Dari gambar di atas dapat disimpulkan bahwa keterampilan dasar mengajar guru sudah meningkat dari siklus sebelumnya dengan adanya tindakan-tindakan perbaikan yang dilakukan oleh kepala sekolah sebagai peneliti sesuai dengan hasil refleksi dari siklus sebelumnya yang akhirnya menyebabkan terdapanya peningkatan. Hal ini berarti melalui penerapan supervisi klinis dapat meningkatkan keterampilan dasar mengajar guru di SDN 165/X Catur Rahayu pada semester ganjil tahun ajaran 2021/2022 melalui tindakan-tindakan sesuai dengan hasil refleksi dari siklus seblumnya.

\section{Refleksi}

Tahap refleksi siklus II dilaksanakan pada hari Kamis tanggal 21 Oktober 2021 dengan dibantu oleh seorang observer yang beranama Siti Zahara, S.Pd. bertempat di ruangan kepala SDN 165/X Catur Rahayu. Berdasarkan ahsil refeleksi di dapat bahwa kendala-kendala yang terjadi pada siklus I dapat diatasa pada siklus II sehingga pelaksanaan supervisi klinis pada siklus II dapat berjalan dengan baik. Hal ini membuat terjadinya peningkatan dari siklus sebelumnya. Oleh karena itu penelitian ini dianggap telah mencapai target ketuntasan pada siklus II dan tidak dilanjutkan ke siklus berikutnya.

\section{Diskusi}

Berdasarkan hasil penelitian didapat bahwa terdapat peningkatan keterampilan dasar mengajar guru dari siklus ke siklus melalui penerapan supervisi klinis. Kinerja mengajar guru menurut Daryono \& Kusuma merupakan suatu prestasi yang dicapai oleh seorang guru dalam pelaksanaan tugasnya selama periode tertentu yang diukur berdasarkan tiga indikator yakni penguasaan bahan ajar, kemampuan mengelola pembelajaran dan komitmen menjalankan tugas 
(Suhayati, 2013). Teori ini digunakan untuk melihat kemampuan mengajar guru apakah sesuai dengan tuntutan standar yang dicapai berdasarkan siswa, sikap siswa, keterampilan siswa, dan perubahan pola kerja guru, apakah semakin meningkat atau sebaliknya. Kemampuan mengajar guru menjadi sangat penting dan menjadi keharusan bagi guru untuk memiliki kemampuan seperti guru harus mampu melakukan inovasi atau kreasi dari materi yang ada di kurikulum.

Supervisi mempunyai makna yang sangat penting dalam upaya meningkatkan dan mengembangkan kegiatan pembelajaran. Namun tak jarang guru merasa takut untuk di supervisi sehingga menghindari ada supervisi. Hal ini karena model dan metode yang akan digunakan dalam supervisi masih menekankan pada mencari kesalahan guru, bukan untuk memperbaikinya. Padahal apabila supervisi dilakukan dengan baik maka akan meningkatkan kemampuan guru.

Jadi Menurut Sagala (2009), supervisi klinis merupakan upaya yang dirancang secara rasional dan praktis untuk memperbaiki kualitas guru di dalam kelas dengan tujuan untuk mengembangkan profesionalitas guru dan perbaikan pengajaran. Melalui pelaksanaan supervisi dengan pendekatan kolaboratif, guru akan dibimbing secara langsung dalam rangka membantu guru guna dapat meningkatkan keterampilan dasar untuk mengajar sehingga diharapkan kompetensi guru akan meningkat dalam pelaksanaan pembelajaran di dalam kelas.

\section{KESIMPULAN}

Berdasarkan hasil penelitian dan pembahasan dapat disimpulkan bahwa supervisi klinis dapat meningkatkan keterampilan dasar mengajar guru di SDN 165/X Catur Rahayu pada semester ganjil tahun ajaran 2021/2022. Hal ini ditandai dengan peningkatan persentase ketuntasan yang terjadi dari siklus I ke siklus II. Dengan menggunakan pendekatan supervisi klinis adalah suatu pendekatan dalam supervisi yang dianggap efektif untuk meningkatkan keterampilan guru dalam proses pembelajaran.

Berdasarkan simpulan dan implikasi penelitian ini, maka dapat disarankan beberapa hal, yaitu: 1) Guru diharapkan dapat untuk meningkatkan satu keterampilan dasar mengajarnya dalam setiap proses pembelajaran di kelas dan terus membuka diri terhadap perbaikan dan supervisi yang dilakukan, 2) Kepala sekolah disarankan untuk melakukan supervisi secara rutin terhadap gurunya khususnya dengan dan melakukan supervisi klinis dan juga memfasilitasi guru untuk dapat meningkatkan berbagai macam kemampuan dan keterampilannya, 3) Pengawas sekolah disarankan untuk meningkatkan pelaksanaan dalam supervisi kepada guru dan sekolah binaannya baik dari segi kualitas maupun kuantitasnya, 4) Dinas pendidikan disini agar senantiasa memfasilitasi upaya yang dilakukan guna dalam meningkatkan kemampuan guru dan pengawas sekolah yang ada.

\section{REFERENSI}

Alma. (2009). Guru Profesional. Bandung: Alfabeta.

Asril zainal. (2010). Micro Teaching. Jakarta: PT. Raja grafindo persada. 
Penerapan Supervisi Klinis untuk Meningkatkan Keterampilan Dasar Mengajar Guru di SDN 165/X Catur Rahayu pada Semester Ganjil Tahun Ajaran 2021/2022, Siti Muslimah

Bafadal, Ibrahim. (2004). Pengelolaan Perlengkapan Pendidikan di Sekolah. Jakarta: Bumi Aksara.

Barnawi dan Mohammad Arifin. (2014). Kinerja Guru Profesional: Instrumen Pembinaan, Peningkatan dan Penilaian. Jogjakarta: AR-RUZZ MEDIA.

Burhanuddin. (1994). Analisis Administrasi Manajemen Dan Kepemimpinan Pendidikan. Jakarta: Bumi Aksara.

E. Mulyasa. (2005). Menjadi Guru Profesional. Bandung: PT. Remaja Rosda Karya.

Helmiati. (2013). Micro teaching: Melatih keterampilan dasar mengajar. Yogyakarta: Aswaja Pressindo.

Ida, Rachmah. (2014). Metode Penelitian: Studi Media dan Kajian Budaya. Jakarta: Kencana.

Idris. (2008). Teknik Evaluasi Dalam Pendidikan Dan Pembelajaran. Bandung: Cita pustaka Media Perintis

Kunandar. (2007). Guru Profesional Implementasi Kurikulum Tingkat Satuan. Pendidikan dan Sukses dalam Sertifikasi Guru. Jakarta: Raja Grafindo.

Marno dan M. Idris. (2014). Strategi dan Metode Pengajaran. Jogjakarta: Ar-Ruzz. Media.

Pidarta. (1999). Peranan Kepala Sckolah Pada Pendidikan Dasar. Jakarta: PT. Grasindo.

Purwanto. (2010). Evaluasi Hasil belajar. Yogyakarta: Pustaka Pelajar.

Sagala, Syaiful. (2009). Konsep dan Makna Pembelajaran. Bandung: CV. Sahri,

Sagala, Syaiful. (2013). Konsep dan Makna Pembelajaran. Bandung: Alvabeta.

Sahertian, Piet A. (2000). Konsep Dasar dan Teknik Supervisi Pendidikan. Jakarta: PT. Rineka Cipta

Soetjipto dan Kosasih, R. (1994). Profesi Keguruan. Jakarta: Ditjen Dikti.

Suhayati, Ely \& Anggadini, Sri Dewi. (2013). Akuntansi Keuangan. Yogyakarta. Graha Ilmu.

Suwarna, P. I. (2013). Analisis Miskonsepsi Siswa Kelas X pada Mata Pelajaran Fisika Melalui CRI

(Certainty of Responses Index) Termodifikasi.FITK UIN Syarif Hidayatullah, Jakarta. hlm. 1-15.

Usman Uzer. (1999). Menjadi Guru Profesional. Bandung : PT Remaja Rosdakarya. 